\title{
Commercial Bank Selection Process Used by Individual Customers: Factor Analysis on Banks of Bangladesh
}

\author{
AFROZA PARVIN* \\ RUMANA PERVEEN**
}

\begin{abstract}
This study is conducted to identify the factors that motivate the customers to select commercial banks for their valuable transactions. Necessary data are collected from 206 respondents. It is found that easy account opening is the most important variable as it has the highest mean value 4.25. From varimax rotation matrix it is observed that responsiveness is the most important factor to customers which includes friendliness, personality, counseling and foreign exchange service. Special services such as loan and deposit schemes, electronic fund transfer service, cash management service, merchant banking, supporting the customer in bad time have also been found as important. Convenience, assurance, reliability and safety factors are also of considerable importance to customers to choose a bank.
\end{abstract}

Keywords: Bank Selection Decision, Factor Analysis, Individual, Bangladesh

\section{INTRODUCTION}

This research tries to explore the factors that motivate the individual customers to select their banks. In this article descriptive statistics and factor analysis have been conducted to identify the factors that get highest, moderate and lowest priority in bank selection decision. As decision criterion maximum customers attached ranking no.01 to 'account opening is easy' and rank no. 20 to 'zero balance facility'. From factor analysis has shown that the factor responsiveness(friendly employees, personality of officers, counseling service, foreign exchange services) acts as the first factor and safety(deposit level is not fluctuating) operates as the last factor.

At present 47 banks are operating in Bangladesh and commercial banking system dominates the country's financial sector. Bangladesh Bank is the Central

\footnotetext{
* Assistant Professor of Finance, Northern University Bangladesh, Khulna Campus.

** Senior Lecturer in Marketing, Northern University Bangladesh, Khulna Campus.
} 
Bank of Bangladesh and the chief regulatory authority in the sector. The Nobelprize winning Grameen Bank is a specialized micro-finance institution which revolutionized the concept of micro-credit and contributed greatly towards poverty reduction and women empowerment in Bangladesh. Private banking sector is the highest growth sector due to the dismal performances of state-owned banks. They tend to offer better services and products. Besides, in 2012 Bangladesh Government also permitted six new banks to operate. They are Union Bank, Modhumati Bank, The Farmers' Bank, Midland Bank, Meghna Bank, South Bangla Agriculture and Commerce Bank (wikipedia.com accessed on 18.09.2012).

Bank is a financial institution that deals in money and it is very important for the economic development of a country. That is why bank selection decision plays a very vital role for an individual customer. A good bank is a necessity and sits at the center of most of our financial accounts (smartmoney.com accessed on 20.09.2012). Financial services marketers certainly spend a lot of time and effort in understanding why people choose to bank with them or decide to bank with a competitor (blog.compete.comaccessed on 21.09.2012). Competition is the buzz word in the present era of globalization. Commercial banks are trying to differentiate them by introducing innovative products and services.

\section{LITERATURE REVIEW}

Andaleb and Conway (2006) have determined the factors that play role for customer satisfaction in the restaurant industry by using regression model and found that responsiveness of the front line employees followed by food price and quality are the key factors for satisfaction. But physical design and appearance of the restaurants are not significant in this regard.

Hanudin Amin and T. Ramayah (2010) have conducted a study to identify therelationship among attitude, service form, perceived security, privacy and intention to use SMS banking.

Jean-Michel Sahut (2008) has analyzed the key factors affecting the adoption of e-wallets by using the Technology Acceptance Model. The key factors of success of this payment method are security, anonymity of transactions, the cost of transactions as well as the plurality of functions (payment, travel card, e-key for building access etc).

Katirchioglu, Tumer and Kilinc (2011) have investigated the bank selection criteria of customers in Romania and have found the Automated Teller Machines 
(ATM) to be the most important selection criterion. In addition, availability of telephone and internet banking, confidentiality of bank customer record, reputation and image of the bank, presentable appearance of the bank staff and number of branch office are also important aspect to the customers.

Li LiEng and Hwee Shan Aw (2000)haverevealed that the demand by large investors to purchase IPOs (initial public offering) is positively associated with earnings yield, firm size and under pricing, and negatively associated with bookto-market ratio.

Maiyaki (2011) has identified the factors that affect retail banking customers' bank selection and preference decision. Here, bank's total asset and availability of larger branch network have a great influence in bank selection decision whereas attractiveness of bank's branches, loan charges are less influential. But attractive loan charge is found insignificant in this study due to religious belief of the customers.

MaranMarimuthu et al., (2010) has foundthat cost-benefits, service delivery, convenience, friends' influence have significant relationships with the acceptance of Islamic banking.

Mokhlis, Salleh and Mat (2009) have conducted an empirical study on bank selection criteria used by single and multiple bank users in Malaysia. Attractiveness, branch location, ATM service, financial benefits, and secure feeling make the difference between single and multiple bank users. Mostly female students have been found engaged in multiple bankinghabits.

Muhammad Abduh and Mohammad Azmi Omar (2012) have done a research in order to identify the Islamic bank selection criteria. The result has shown that shariah complaint attribute is the highest priority before an individual to patronize Islamic banks. The next priorities are given to profitability, bank's reputation, bank's status, facilities and services and friendly personnel respectively.

MurisCicic, NernadBrkic and Emir Agic (2004)haverevealed that the main factors determining students' bank selection decision are reception at the bank, friendliness of the bank personnel, low service charge, ease of opening current account and confidence in bank management.

Nour-Mohammad Yaghoubi and Bahmani (2010) have identified the factors that affect online banking and it has been found that online banking service 
adoption can be explained in terms of perceived behavioral control, perceived usefulness, perceived ease of use, subjective norm and attitude.

Parvin and Hossain (2010) have found that respondents are satisfied by using debit card either for taka withdrawal or goods purchase or forbothpurposes. But respondents want more ATM booth, network facility, transaction receipt, and all types of value denominated notes to be more satisfied.

SafiekMokhlis et al., (2008) state that the bank selection decision is based primarily on nine selection criterion. They are secure feeling, ATM service, provision, proximity, branch location, non-people influential, attractiveness and people influences.

Rao and Sharma (2010) havecome across that employees' courtesy, parking facility, loyalty program, brand name, security system and low charges are the most important factors for bank selection decision. Motivation for the customers to select their banks are responsiveness, value added services and convenience, zero balance, speedy service, and good rate of interest etc.

Shaher, Kasawneh and Salem (2011) have used factor analysis technique to find out factors related to bank performance and found bank characteristics as the most important factorand other factor as the least important factor.

UgurYavas, EminBabakus, Nicholas J. Ashilhave stated that banks should keep up the good work in terms of their staff quality, being trustworthy, fees and convenience location to fulfill the demands of their customers.

Waleed Al-Ghaith, Louis Sanzogni and Sandhu (2010) have identified perceived complexity (the most significant factor), privacy and compatibility, quality of the internet and its relative advantage affect the e-service adoption in Saudi Arabia.

\section{OBJECTIVES OF THE RESEARCH}

The main objective of this research is to identify the factors that influence individual customers to select their commercial banks. The specific objectives are:

i. To know the factors that are getting more priority and the other factors which are getting less priority for bank selection decision.

ii. To examine whether demographic factors of the respondents have any significant effect on making decisions. 
iii. To recommend some suggestions for the bank management team that will help them attract more customers through sophisticated services.

\section{RESEARCH METHODOLOGY}

This research is mainly based on primary data collected with a structured questionnaire consisting of twenty questions taking help from previous research (Rao and Sharma). Likert-type five point scale has been used where value 1 is assigned to the answer strongly disagree, 2 to disagree, 3 to neutral, 4 to agree and 5 to strongly agree answer for each question. The questionnaire is divided into two parts. Demographic profile of the respondents is the first part and in the second part bank selection factors related questions areplaced.A total of 206 customers have been surveyed using simple random sampling method.At first, the questionnaire was pre-tested with a sample size of 25. Data are collected from both the conventional banks and Islamic banks' customers. Then necessary corrections and additions are then made to make the questionnaire more meaningful and useful to attain the objectives of the research. On the other hand, secondary data have been collected from different articles and websites. Collected data have been analyzed and presented using descriptive statistics (frequency table, mean and standard deviation), factor analysis techniques using varimax rotation (Principal Component Analysis) to find out the factors that are the most or least important role players for bank selection decision. To test the reliability of the data, Cronbach's alpha has been calculated. At last Chi square test has been conducted to justify objective no. 02 for which the following hypotheses are drawn:

$\mathrm{H}_{0}$ : There is no significant effect of demographic factors on bank selection decision.

$\mathrm{H}_{\mathrm{a}}$ : There is significant effect of demographic factors on bank selection decision

For all analyses SPSS software version 16.0 has been used. 


\section{EMPIRICAL FINDINGS AND ANALYSIS}

TABLE 1

DEMOGRAPHIC PROFILE OF THE RESPONDENTS

\begin{tabular}{|c|c|c|c|}
\hline Characteristics & Category & Frequency & Percent \\
\hline \multirow[t]{3}{*}{ Sex } & Male & 156 & 75.7 \\
\hline & Female & 50 & 24.3 \\
\hline & Total & 206 & 100.0 \\
\hline \multirow[t]{5}{*}{ Age } & $15-25$ years & 127 & 61.7 \\
\hline & $25-35$ years & 65 & 31.6 \\
\hline & $35-45$ years & 10 & 4.9 \\
\hline & $45 \&$ above & 4 & 1.9 \\
\hline & Total & 206 & 100.0 \\
\hline \multirow[t]{4}{*}{ Marital status } & Single & 147 & 71.4 \\
\hline & Married & 54 & 26.2 \\
\hline & Divorced/Separated & 5 & 2.4 \\
\hline & Total & 206 & 100.0 \\
\hline \multirow[t]{6}{*}{ Education level } & Below SSC & 11 & 5.3 \\
\hline & SSC & 7 & 3.4 \\
\hline & HSC & 64 & 31.1 \\
\hline & Undergraduate & 58 & 28.2 \\
\hline & Graduate/Postgraduate & 66 & 32 \\
\hline & Total & 206 & 100.0 \\
\hline \multirow[t]{6}{*}{ Occupation } & Student & 126 & 61.2 \\
\hline & Service holder & 51 & 24.8 \\
\hline & Businessman & 13 & 6.3 \\
\hline & Housewife & 6 & 2.9 \\
\hline & Others & 10 & 4.9 \\
\hline & Total & 206 & 100.0 \\
\hline \multirow{6}{*}{$\begin{array}{l}\text { Monthly Income } \\
\text { level }\end{array}$} & Taka $0-10,000$ & 134 & 65.0 \\
\hline & Taka $10,000-20,000$ & 31 & 15.0 \\
\hline & Taka 20,000-30,000 & 24 & 11.7 \\
\hline & Taka 30,000-40,000 & 7 & 3.4 \\
\hline & Taka 40000 - above & 10 & 4.9 \\
\hline & Total & 206 & 100 \\
\hline \multirow{3}{*}{$\begin{array}{l}\text { Types of Bank } \\
\text { respondents use }\end{array}$} & Conventional bank & 179 & 86.9 \\
\hline & Islamic bank & 27 & 13.1 \\
\hline & Total & 206 & 100 \\
\hline
\end{tabular}

Source: Field Survey, September, 2012 
The demographic characteristics of the respondents revealthatthe majority of the respondents are male $(75.7 \%)$ and only $24.3 \%$ of the respondents are female, of them $71.4 \%$ are single while $26.2 \%$ and $2.4 \%$ are married and divorced/separated respectively. The agelevelof $61.7 \%$ respondents is between 15 and 25 years, $31.6 \%$ between 25 and 35 years, $4.9 \%$ between 35 and 45 and $1.9 \%$ is from 45 to above.

Maximum respondents are well educated.Here, $32 \%$ has passed postgraduate level, $28 \%$ has passed undergraduate level, $31.1 \% \mathrm{HSC}$ level and only $8.7 \%$ falls into SSC passed or below SSClevel.Most of the respondents are students and a few of themare housewives.

Most ofthem earn monthly less than Tk. 10,000 and a very low (4.9\%) earn highest level of income. This research has used $86.9 \%$ sample form conventional banks and $13.1 \%$ from Islamic banks.

TABLE 2

KMO AND BARLETT'S TEST

\begin{tabular}{|lcc|l|}
\hline \multicolumn{2}{|l|}{ Kaiser-Meyer-Olkin Measure of Sampling } & .720 \\
Adequacy.' & & 769.841 \\
Bartlett's & Test & of Approx. Chi-Square & 190 \\
Sphericity & & Df & .000 \\
& Sig. & \\
\hline
\end{tabular}

Source: Field Survey, September-2012

Kaiser-Meyer-Olkin Measure of Sampling Adequacy (MSA) for individual variance wasstudied and it reveals that there is sufficient correlation among all the variables. To testthe sampling adequacy Kaiser-Meyer-Olkin MSA is computed which is found to be 0.720 and it indicates that sample is good enough (Rao \& Sharma) and can be used forfurther analysis. The overall significance of correlation matrices is tested with Barlett'sTest of Sphericity .It provides support for the validity of the factor analysis of the dataset. The above Table shows that the sample is appropriate and significant for the work. 


\section{Reliability Analysis}

Reliability refers to the consistency of a measure. A test is considered reliable if we get the same result repeatedly (psychology.about.com accessed on 13.10.2012). In the following Table, reliability of the collected data has been calculated by calculating Cronbach's alpha. Cronbach's alpha is widely believed to indirectly indicate the degree to which a set of items measures a single unidimensional latent construct (Wikipedia accessed on 05.10.2012). Cronbach's alpha will generally increase as the intercorelations among test items increase, and is thus known as an internal consistency estimate of reliability of test scores because intercorelations among test items are maximized when all items measure the same construct.

TABLE 3

\section{RELIABILITY RESULT}

\begin{tabular}{|c|c|c|}
\hline Cronbach's Alpha & No. of Items & No. of Respondents \\
\hline .749 & 27 & 206 \\
\hline
\end{tabular}

Source: Field Survey, September-2012

\section{Ranking Importance of the Variables:}


TABLE 4

RANKING IMPORTANCE OF DIFFERENT VARIABLES RELATED TO BANK SELECTION

\begin{tabular}{|l|r|r|r|c|}
\hline \multicolumn{1}{|c|}{ Variables } & N & Mean & \multicolumn{1}{|l|}{$\begin{array}{l}\text { Std. } \\
\text { Deviation }\end{array}$} & $\begin{array}{l}\text { Ranking } \\
\text { of the } \\
\text { variables }\end{array}$ \\
\hline Location and design is attractive & 206 & 4.24 & .872 & 2 \\
\hline Account opening is very easy & 206 & 4.25 & .943 & 1 \\
\hline Bank provides huge amount of loan & 206 & 3.56 & 1.061 & 16 \\
\hline Bank provides parking facility & 206 & 3.36 & 1.339 & 19 \\
\hline Bank provides zero balance facility & 206 & 2.94 & 1.532 & 20 \\
\hline $\begin{array}{l}\text { The profile of management team is } \\
\text { very high }\end{array}$ & 206 & 3.96 & .952 & 6 \\
\hline $\begin{array}{l}\text { Bank provides creative banking } \\
\text { facility }\end{array}$ & 206 & 3.91 & .964 & 7 \\
\hline $\begin{array}{l}\text { Deposit level of the bank is not } \\
\text { fluctuating }\end{array}$ & 206 & 3.90 & .980 & 8 \\
\hline Services of the bank are good & 206 & 4.11 & .989 & 3 \\
\hline $\begin{array}{l}\text { Bank provides attractive credit } \\
\text { facility }\end{array}$ & 206 & 3.81 & 1.013 & 11 \\
\hline $\begin{array}{l}\text { Bank provides mobile banking } \\
\text { service }\end{array}$ & 206 & 3.53 & 1.487 & 17 \\
\hline $\begin{array}{l}\text { Bank has special loans and deposit } \\
\text { schemes }\end{array}$ & 206 & 4.04 & .964 & 4 \\
\hline Bank provides merchant banking & 206 & 3.89 & 1.051 & 9 \\
\hline $\begin{array}{l}\text { Bank provides electronic fund } \\
\text { transfer service }\end{array}$ & 206 & 3.97 & 1.162 & 5 \\
\hline $\begin{array}{l}\text { Bank provides cash management } \\
\text { services }\end{array}$ & 206 & 3.84 & 1.111 & 10 \\
\hline $\begin{array}{l}\text { Bank provides foreign exchange } \\
\text { service }\end{array}$ & 206 & 3.73 & 1.174 & 15 \\
\hline $\begin{array}{l}\text { Bank officers provide counseling to } \\
\text { the clients }\end{array}$ & 206 & 3.78 & 1.143 & 14 \\
\hline Bank employees are friendly & 206 & 3.79 & 1.207 & 13 \\
\hline $\begin{array}{l}\text { The personality of the officers is very } \\
\text { strong to customers }\end{array}$ & 206 & 3.80 & 1.076 & 12 \\
\hline $\begin{array}{l}\text { The bank supports the customer's } \\
\text { activity in bad time }\end{array}$ & 206 & 3.40 & 1.184 & 18 \\
\hline Source: Field Survey, September, 2012 & & & \\
\hline
\end{tabular}

Source: Field Survey, September, 2012 
From the Table 4, it is clear that easy account opening has got the highest priority with mean value of 4.25 , location and design (4.24), services of the bank (4.11) and special loans and deposit schemes (4.04) of the banks are the most important factors to the customers as they have higher mean value. The customers rated them high as they considered they are very much important. Electronic fund transfer service (3.97), profile of management team (3.96), creative banking facility (3.91), deposit level of bank (3.90), merchant banking (3.89), cash management service (3.84), attractive credit facility (3.81), personality of bank personnel (3.80), friendliness of employees (3.79), counseling services (3.78), foreign exchange services (3.73) are also important to customers before selecting bank.

On the other hand, the customers give less attention to the variables such as getting huge amount of loan (3.56), mobile banking services (3.53), and getting support during bad time (3.40), parking facility (3.36) and zero balance facility (2.94) when they choose banks.

\section{Factor Analysis}

Factor Analysis is a data reduction statistical technique that allows simplifying the co-relational relationships between a number of continuous variables (Rao and Sharma). Principal component analysis is a variable reduction procedure. It is useful when anyone obtains data on a number of variables (possibly a large number of variables), and believes that there is some redundancy in those variables. In this case, redundancy means that some of the variables are correlated with one another, possibly because they are measuring the same construct. Because of this redundancy, one believes that it should be possible to reduce the observed variables into a smaller number of principal components (artificial variables) that will account for most of the variance in the observed variables.

Because it is a variable reduction procedure, principal component analysis is similar in many respects to exploratory factor analysis. In fact, the steps followed when conducting a principal component analysis are virtually identical to those followed when conducting an exploratory factor analysis. However, there are significant conceptual differences between the two procedures (support.sas. accessed on 02.10.2012) 
TABLE 5

COMMUNALITIES OF DIFFERENT VARIABLES RELATED TO

BANK SELECTION

\begin{tabular}{|l|c|c|}
\hline & Initial & Extraction \\
\hline location and design is attractive & 1.000 & .660 \\
account opening is very easy & 1.000 & .617 \\
bank provides huge amount of loan & 1.000 & .599 \\
bank provides parking facility & 1.000 & .780 \\
bank provides zero balance facility & 1.000 & .637 \\
the profile of management team is very high & 1.000 & .548 \\
bank provides creative banking facility & 1.000 & .669 \\
deposit level of the bank is not fluctuating & 1.000 & .777 \\
services of the bank are good & 1.000 & .690 \\
bank provides attractive credit facility & 1.000 & .575 \\
bank provides mobile banking service & 1.000 & .612 \\
bank has special loans and deposit schemes & 1.000 & .435 \\
bank provides merchant banking & 1.000 & .422 \\
bank provides electronic fund transfer service & 1.000 & .568 \\
bank provides cash management services & 1.000 & .627 \\
bank provides foreign exchange service & 1.000 & .589 \\
bank officers provide counseling to the clients & 1.000 & .489 \\
bank employees are friendly & 1.000 & .724 \\
the personality of the officers is very strong to & 1.000 & .565 \\
customers & 1.000 & .487 \\
the bank supports the customer's activity in bad time & &
\end{tabular}

Extraction Method: Principal Component Analysis.

Source: Field Survey, September, 2012

The proportion of variance in any one of the original variables, which is being captured by the extracted factor, is known as communality (Nargundkar, 2002). Communalities Table tells us that after seven factors are extracted and retained in rotated component matrix the communality is 0.660 for variable 1 , 0.617 for variable 2 and so on. It means $60.34 \%$ of the variance of variable 1 is being captured by the seven extracted factors together. 
TABLE 6

ROTATED COMPONENT MATRIX

\begin{tabular}{|c|c|c|c|c|c|c|c|}
\hline \multirow[t]{2}{*}{ Measures } & \multicolumn{7}{|c|}{ Factor loading } \\
\hline & 1 & 2 & 3 & 4 & 5 & 6 & 7 \\
\hline \multicolumn{8}{|l|}{ Responsiveness } \\
\hline Bank employees are friendly & 0.792 & & & & & & \\
\hline $\begin{array}{l}\text { The personality of the officers is very } \\
\text { strong to customers }\end{array}$ & 0.681 & & & & & & \\
\hline $\begin{array}{l}\text { Bank officers provide counseling to the } \\
\text { clients }\end{array}$ & 0.634 & & & & & & \\
\hline $\begin{array}{l}\text { The bank provides foreign exchange } \\
\text { service }\end{array}$ & 0.499 & & & & & & \\
\hline \multicolumn{8}{|l|}{ Special services } \\
\hline $\begin{array}{l}\text { The bank has special loan and deposit } \\
\text { schemes }\end{array}$ & & 0.635 & & & & & \\
\hline $\begin{array}{l}\text { The bank provides electronic fund } \\
\text { transfer service }\end{array}$ & & 0.628 & & & & & \\
\hline $\begin{array}{l}\text { The bank provides cash management } \\
\text { services }\end{array}$ & & 0.591 & & & & & \\
\hline The bank provides merchant banking & & 0.565 & & & & & \\
\hline $\begin{array}{l}\text { The bank supports the customer in bad } \\
\text { time }\end{array}$ & & 0.416 & & & & & \\
\hline \multicolumn{8}{|l|}{ Convenience } \\
\hline $\begin{array}{l}\text { The bank provides creative banking } \\
\text { facility }\end{array}$ & & & 0.745 & & & & \\
\hline $\begin{array}{l}\text { The bank provides attractive credit } \\
\text { facility }\end{array}$ & & & 0.645 & & & & \\
\hline $\begin{array}{l}\text { Convenient location and design of the } \\
\text { bank is attractive }\end{array}$ & & & 0.630 & & & & \\
\hline Account opening is very easy & & & 0.566 & & & & \\
\hline \multicolumn{8}{|l|}{ Assurance } \\
\hline The bank provides zero balance facility & & & & 0.788 & & & \\
\hline Profile of management team is high & & & & 0.443 & & & \\
\hline \multicolumn{8}{|l|}{ Reliability } \\
\hline The bank provides parking facility. & & & & & 0.839 & & \\
\hline The bank provides huge amount of loan & & & & & 0.671 & & \\
\hline \multicolumn{8}{|l|}{ Special Service } \\
\hline $\begin{array}{l}\text { The bank provides mobile banking } \\
\text { facility }\end{array}$ & & & & & & 0.664 & \\
\hline Services of banks are good & & & & & & -0.496 & \\
\hline \multicolumn{8}{|l|}{ Safety } \\
\hline Deposit level of bank is not fluctuating & & & & & & & 0.811 \\
\hline Eigen value & 3.929 & 1.9 & 1.508 & 1.387 & 1.259 & 1.070 & 1.016 \\
\hline Variance explained (\%) & 19.647 & 9.502 & 7.54 & 6.933 & 6.297 & 5.351 & 5.078 \\
\hline Cumulative variance explained (\%) & 19.647 & 29.149 & 36.689 & 43.622 & 49.919 & 55.27 & 60.348 \\
\hline
\end{tabular}

Extraction Method: Principal Component Analysis.

Rotation Method: Varimax with Kaiser Normalization.

Rotation converged in 19 iterations

Source: Field Survey, September-2012 
Loading on factors can be positive or negative. A negative loading indicates that this variable has an inverse relationship with the rest of the factors. The higher the loading the more important is the factor (Rao \& Sharma). However,Comrey (1973) suggested that anything above 0.44 could be considered salient, with increased loading becoming more vital in determining the factor. Factor analysis was conducted with varimax rotation to examine how the selected measures loaded on expected constructs. Seven factors were recovered from the analysis with Eigen value greater than 1 . The Eigen values represent a partition of the total variation in the multivariate sample (www.jmp.comaccessed on05.10.2012). They sum to the number of variables when the principal components analysis is done on the correlation matrix. Eigen values for seven factors were $3.929,1.9,1.508,1.387,1.259,1.070$, and 1.016. The total cumulative variation explained by factor analysis was 60.34 percent. The first factor explained $19.647 \%$ of total variance; whereas the second factor $9.502 \%$, the third factor $7.540 \%$, the fourth factor $6.933 \%$, the fifth factor $6.297 \%$, the fifth factor $5.351 \%$ and the last factor explicated $5.078 \%$ of total variance.

\section{Discussion on Rotated Factor Analysis:}

\section{The First Factor: Responsiveness}

The first factor that can be called as responsiveness is the most important factor in the study. There are four variables including friendliness, personality, counseling and foreign exchange service ranked on their communalities. Friendliness was found as the most important variable whileforeign exchange serviceasthe least important variable in this factor. Personality and counseling service were also included under this factor.

\section{The Second Factor: Special services}

The second factor called as special services, which is considered the second most important factor in the study, contains five variables ranked based on their communalities. Special loan and deposit schemes were the most important variable (0.635) and supporting customers in bad time was the least important variable (0.416) in this factor. Electronic fund transfer service, cash management services and merchant banking were included under this service.

\section{The Third Factor: Convenience}

The third factor known as convenience contains four variables ranked based on their communalities. Creative banking facility was the most important variable in this section. Attractive credit facility, location and design of the bank came after creative banking. Attractive account opening was the least important variable in this factor. 


\section{The Fourth Factor: Assurance}

The fourth factor, assurance, which is considered the fourth most important variable in the study, contains two variables zero balance facility - the most important variable and high profile of management team - the least important variable in this factor.

\section{The Fifth Factor: Reliability}

The fifth factor which we called 'reliability' has two variables such as parking facility of the bank (0.839) and huge amount of loan facility $(0.671)$.

\section{The Sixth Factor: Special Service}

The sixth factor named as 'special service' contains two variables ranked based on communalities. One is Mobile Banking facility and another is good services of the bank.

\section{The Seventh Factor: Safety}

The seventh factor, which is called other factor, contains one variable ranked based on communalities. Non fluctuating deposit level of bank was the most and only important variable in this section.

Hypothesis Testing: A Chi-square test is a statistical test commonly used for testing independence and goodness of fit. Testing independence determines whether two or more observations across two populations are dependent on each other that is, whether one variable helps to estimate the other (www.chegg.com/homework-help accessed on). In the following Table the results of Chi-square test of demographic variables are shown:

TABLE 7 TEST STATISTICS

\begin{tabular}{|l|r|r|r|r|r|r|r|}
\hline & \multicolumn{1}{|c|}{ Sex } & \multicolumn{1}{c|}{ Age } & $\begin{array}{c}\text { Marital } \\
\text { Status }\end{array}$ & $\begin{array}{c}\text { Educationa } \\
\text { llevel }\end{array}$ & $\begin{array}{c}\text { Professio } \\
\mathbf{n}\end{array}$ & Income & Bank type \\
\hline Chi-Square & 54544 & 191476 & 151524 & 84922 & 249874 & 270748 & 112155 \\
Df & 1 & 3 & 2 & 4 & 4 & 4 & 1 \\
p-value & .000 & .000 & .000 & .000 & .000 & .000 & .000 \\
Comment & Significant & Significan & Significant & Significant & Significant & Significant & Significant \\
\hline
\end{tabular}

Source: Field Survey, September-2012

From the above Table it is seen that all the p-values are less than 0.01 and 0.05 . So, here alternative hypothesis is accepted and it can be inferred that all 
demographic variables (sex, age, marital status, educational level, profession, income and type of bank in which customers do their transaction) have significant effect on the bank selection decision at $1 \%$ as well as $5 \%$ level of significance.

\section{CONCLUSION AND RECOMMENDATIONS}

Banking sector is the most prominent and competitive sector in Bangladesh. Various banks are working to stay ahead of their competitors by providing efficient services to customers. In our study we have found that customers give most attention to the factors such as openness, personality, counseling service etc. So, the banks that maintain these factors should continue it and the banks that do not maintain must start adopting these factors immediately. However, according to the results found in this study the following recommendations are suggested for the banking sector of Bangladesh:

i. Convenient location is important to customers because they do not want to waste their time. The banks should give proper attention on improving the location.

ii. Different types of special services should be added in the service line to motivate customers, management team should be experts and bankers should stay close to the customers when customers are in financial problem.

iii. Customers prefer parking facility provided by the bank so that they can spend time in the bank to complete their financial transaction smoothly. The banks should give proper attention to it.

iv. Zero balance facility is expected by the customers when they choose their bank. Thus, the bank should provide zero balance facility so that the customers' accounts are kept open although there is no balance in their accounts.

v. The customers do not want to waste their time in standing in a long queue. The banks should provide speedy, customized and value added services such as ATM, E-Banking, and Phone Banking to influence the customers.

vi. Banks should give proper attention to train up their employees. 


\section{REFERENCES}

Afroza Parvin, M. S. (2010). Satisfaction of Debit Card Users in Bangladesh: A Study on Some Private Commercial Banks. Journal of Business and Technology (Dhaka), 5 (2), 88-103.

A Sajeevan Rao, R. K. (2010). Bank selection Criteria Employed by MBA Students in Delhi: An Empirical Analysis. Journal of Business Studies Quaterly, 1 (2), 5669.

Comrey, A.L. (1973). A First Course in Factor Analysis. San Diego: Academic Press.

Hanudin Amin, T. R. (2010). SMS Banking: Explaining The Effects of Attitude,Social Norms and Perceived Security and Privacy. The Electronic Journal on Information Systems in Developing Countries, 41 (2), 1-15.

Li Li Eng, H. S. (2000). An Analysis of Factors Affecting Investor Demand for Initial Public Offerings in Singapore. Multinational Finance Journal, 4 (1,2), 133-153.

Maiyaki, A. A. (2011). Factors Determining Bank's Selection and Preference in Nigerian Retail Banking. International Journal of Business and Management, 6 (1).

Maran Marimuthu, C. W. (2010). Islamic Banking: Selection Criteria and Implications. Global Journal of Human Social Science, 10 (4), 52-62.

Muhamad Abduh, M. A. (2012). Islamic-BAnk Selection Criteria in Malaysia: An AHP Approach. Business Intelligence Journal , 271-281.

Muris Cicic, N. B. (n.d.). Bank Selection Criteria Employed by Students in a Southeastern European Country: An Empirical Analysis of Potential Market segmentsPreferences available at www.scholargoogle.com accessed on 25.09.12 at $4.00 \mathrm{pm}$

Nargundkar, Rajendra (2002). Marketing Research: Text and Cases, Tata McGraw Hill, New Delhi.

Nour-Mohammad Yaghoubi, E. B. (2010). Factors Affecting the Adoption of Online Banking: An Integration of Technology Acceptance Model and Theory of Planned Behavior. International Journal of Business and Management, 5 (9).

Safiek Mokhlis, H. S. (2009). Commercial bank Selection : Comparison Between Single and Multiple bank Users in Malaysia. International Journal of Economic and Finance, 1 (2), 263-273. 
Safiek Mokhlis, N. H. (2008). Commercial Bank Selection: The Case of Undergraduate Students in Malaysia. International Review of Business Research Papers, 4 (5), 258-270.

Sahut, J.-M. (2008). The Adoption and Diffusion of Electronic Wallets: The Case of Moneo. Journal of Internet Banking and Commerce, 13 (1).

Salih Turan Katircioglu, M. T. (2011). Bank selection criteria in the banking industry: An Empirical Investigation from Customers in Romanian Cities. African Journal of Business Management, 5(14), 5551-5558.

Syed Saad Andaleeb, C. C. (2006). Customer Satisfaction in the restaurant Industry: an examination of the Transaction-Specific Model. Journal of Service Marketing, 20 (1), 3-11.

Thair Al Shaher, O. K. (2011). The Major Factors that Affect Bank's Performance in Middle Eastern Countries. Journal of Money, Investment and Banking (20).

Ugur Yavas, E. B. (n.d.). What Do Customers Look for in a Bank? An Empirical Study. Accessed on www.google.com. retrived at 2:00pm

Waleed Al-Ghaith, L. S. (2010). Factors Influencing the Adoption and Usage of Online Services in Saudi Arabia. The Electronic Journal of Information System in Developing Countries, 40 (1), 1-32.

\section{Websites:}

○ www.blog.compete.com accessed on 21.09.2012

○ www.chegg.com/homework-help/definitions/chi-square-test-31accessedon 07.10 .2012

○ Www.google.com accessed on20.10.2012

○ www.jmp.com accessed on 05.10.2012

○ www.psychology.about.com accessed on 13.10.2012

○ www.smartmoney.com/invest/strategies/how-to-choose-a-bank accessed on 20.09.2012

○ www.support.sas.com/publishing/pubcat/chaps/55129.pdf accessed on 02.10 .2012

○ www.wikipedia.com accessed on 05.10.2012 
